RESEARCH PAPER

\title{
A tobacco industry study of airline cabin air quality: dropping inconvenient findings
}

\author{
K Neilsen, S A Glantz
}

Tobacco Control 2004;13(Suppl I):i20-i29. doi: 10.1136/tc.2003.004721

\begin{abstract}
Objective: To examine an industry funded and controlled study of in flight air quality (IFAQ).
Methods: Systematic search of internal tobacco industry documents available on the internet and at the British American Tobacco Guildford Depository.

Results: Individuals from several tobacco industry companies, led by Philip Morris, designed, funded, conducted, and controlled the presentation of results of a study of IFAQ for the Scandinavian airline SAS in 1988 while attempting to minimise the appearance of industry control. Industry lawyers and scientists deleted results unfavourable to the industry's position from the study before delivering it to the airline. The published version of the study further downplayed the results, particularly with regard to respirable suspended particulates. The study ignored the health implications of the results and instead promoted the industry position that ventilation could solve problems posed by secondhand smoke. Conclusions: Sponsoring IFAQ studies was one of several tactics the tobacco industry employed in attempts to reverse or delay implementation of in-flight smoking restrictions. As a result, airline patrons and employees, particularly flight attendants, continued to be exposed to pollution from secondhand smoke, especially particulates, which the industry's own consultants had noted exceeded international standards. This case adds to the growing body of evidence that scientific studies associated with the tobacco industry cannot be taken at face value.
\end{abstract}

See end of article for authors' affiliations

Correspondence to: Stanton A Glantz, PhD, Box 1390, University of California, San Francisco, CA 94143-1390, USA glantz@medicine.ucsf.edu

$\mathrm{T}$ he first calls for restricting smoking on commercial aircraft came in December 1969, when consumer advocates Ralph Nader and John Banzhaf filed separate petitions with the US Federal Aviation Administration (FAA), which was responsible for aircraft safety. Nader requested ending onboard smoking entirely, characterising smoke as an annoyance and a health hazard. ${ }^{12}$ Banzhaf asked for separate sections for smokers on the grounds that passive smoking was hazardous. ${ }^{3}$ The FAA studied the issue, finding eventually that exposure to tobacco smoke was unlikely to be "injurious to the health of nonsmokers", and declined to take action. The reformers then took their case to the Civil Aeronautics Board ( $\mathrm{CAB})$, which regulated economic issues related to airlines; the $\mathrm{CAB}$ proved more receptive. ${ }^{1}$ These events marked the beginning of a 25 year fight for smoke-free flights worldwide.

By 1972, several US carriers had voluntarily created limited non-smoking sections aboard some or all of their airplanes. ${ }^{45}$ Throughout the 1970s and early 1980s, due largely to the efforts of anti-smoking advocates and airline employees, the $\mathrm{CAB}$ codified that separation by publishing a series of regulations restricting onboard smoking, mandating separate seating of smokers and non-smokers (1973), segregation of cigar and pipe smokers (1979), and provision of a nonsmoking seat to any passenger who requested one (1981). ${ }^{1}$ Tobacco industry response to $\mathrm{CAB}$ actions took many forms, including letter writing campaigns, petition drives, and surveys aimed at persuading the $\mathrm{CAB}$ that the flying public did not support attempts to regulate smoking or that existing restrictions were adequate. ${ }^{6-10}$ During this period, industry opposition to potential restrictions on smoking centred on ideas of unfair or unequal treatment of smokers. ${ }^{11}$

Knowledge of the health dangers of secondhand smoke accumulated rapidly in the 1980s after the first studies linking passive smoking with lung cancer appeared in 1981.1213 Three important scientific consensus documents were published in 1986. The US Surgeon General issued an entire report about secondhand smoke, The health consequences of involuntary smoking, concluding that secondhand smoke caused lung cancer in non-smokers and that "simple separation of smokers and nonsmokers within the same airspace may reduce but cannot eliminate nonsmoker exposure to environmental tobacco smoke [ETS]". ${ }^{14}$ The National Research Council published Environmental tobacco smoke: measuring exposures and assessing health effects, which concluded: "Considering the evidence as a whole, ETS increases the incidence of lung cancer in non-smokers." ${ }^{15}$ Finally, the National Academy of Sciences (NAS) published The airliner cabin environment, which highlighted the problem of secondhand smoke and closed by "unanimously and forcefully proposing that smoking be banned on all commercial flights within the United States". ${ }^{16}$ (The Department of Transportation later rejected the NAS proposal on grounds that further study was needed. ${ }^{17}$ )

The tobacco industry understood the important symbolic value of restricting smoking on airplanes; a 1988 a Philip Morris (PM) report "Action plan for ETS in Europe" recognised that "In-flight restrictions receive broad publicity and encourage the adoption of other prohibitions elsewhere" ${ }^{\prime 18}$ Faced with a direct assault on in-flight smoking coupled with increasing publicity about the dangers of secondhand smoke, the industry adopted the same strategy it had started using in the mid 1980s in efforts to resist demands for smoke-free workplaces and public places ${ }^{19-24}$ :

Abbreviations: $C A B$, Civil Aeronautics Board; $C I A R$, Center for Indoor Air Research; ETS, environmental tobacco smoke; FAA, Federal Aviation Administration; IAQ, indoor air quality; IFAA, International Flight Attendants Association; IFAQ, in flight air quality; NAS, National Academy of Sciences; PM, Philip Morris; RSP, respirable suspended particles; TNO, Nederlandse Organisatie voor Toegepast-

Natuurwetenschappelijk Onderzoek (Netherlands Organization for Applied Scientific Research) 
redirecting attention from secondhand smoke to the broader issue of indoor air quality (IAQ). ${ }^{25-27}$ In 1987, PM began to discuss conducting studies of in flight air quality (IFAQ) with the objective of resisting smoking restrictions and reversing "scientific and popular opinion that ETS is harmful to health". ${ }^{28}$ We describe how PM conceived of, and the industry executed, one such study of air quality on the Scandinavian airline SAS, excised results that did not serve the industry's interests, and eliminated statements regarding the study's health implications.

\section{METHODS}

We analysed tobacco industry documents available on the internet as a result of tobacco litigation. We searched for documents on the following websites: Philip Morris (www. pmdocs.com), the Tobacco Institute (www.tobaccoinstitute. com), Tobacco Documents Online (www.tobaccodocuments. org), the Legacy Tobacco Documents Library (legacy. library.ucsf.edu), and the UCSF British American Tobacco documents collection (www.library.ucsf.edu/tobacco/batco). Searches were conducted from August 2002 to May 2003. We also examined paper copies of British American Tobacco Company documents from the Guildford depository identified in a manual search of the documents conducted in November 2002.

\section{RESULTS \\ IFAQ study}

In 1987, Philip Morris employees identified Scandinavian countries, Sweden and Finland in particular, as priority areas for action because the dangers of secondhand smoke had received extensive media coverage there and because both SAS and Finnair, the national airlines of Sweden and Finland, had contemplated or were preparing to implement smoking restrictions. Moreover, SAS's charter airline, Scanair, planned to offer smoke-free charter flights during the winter of 1988-89. PM employees met with each airline during the summer of 1988 to discuss conducting IFAQ studies, presenting IFAQ studies as a means of addressing an issue that concerned both the tobacco industry and the airline industry: customer preference. ${ }^{17} 28-31$ Finnair declined to participate in an IFAQ study because it might publicly mark them as having an air quality problem ${ }^{32}$; SAS showed more interest, however, perhaps because of its continuing attempts to address the issue of smoke in the cabin.

SAS had tested in-flight smoking restrictions twice, in 1981 and 1983, in response to customer and cabin crew complaints about smoke. Complaints from passengers had increased sharply after the introduction in 1981 of length-wise separation of smokers and non-smokers in DC-9s. Results of a passenger survey taken after the 1983 smoke-free trial indicated strong support for restrictions, especially from nonsmokers. SAS analysts remained concerned, however, that SAS would lose passengers (revenue) if they implemented a permanent smoke-free policy.* ${ }^{33}$ Due to those financial concerns, SAS returned to allowing smoking. However, the report on the 1983 smoke-free trial concluded that an ongoing shift in Scandinavian public opinion would eventually lead to reconsidering such policies. ${ }^{33}{ }^{34}$ Five years later, in the summer of 1988, SAS planned another smoke-free trial. $^{29}$

*This conclusion is surprising based on the actual results of the survey. While $7 \%$ of customers said that they had considered alternative travel arrangements because of the smoke-free policy, 5\% said that they had avoided air travel because of the secondhand smoke. This difference is well within the margin of error associated with the survey. A more accurate conclusion would have been that the policy was having no effect on revenue.
At a 1988 meeting with SAS, PM International's manager of corporate affairs, Mary Pottorff, suggested an IFAQ study funded by the tobacco industry as a means to address both industries' customers' preferences and to provide "scientifically sound, statistically valid data" which could "counter balance" customers who wished "to impose their preference of no smoking on all other passengers". ${ }^{31}$ SAS, searching for a way to satisfy both smoking and non-smoking customers, agreed to cooperate with the tobacco industry funded study. ${ }^{31} 35$

\section{The tobacco industry and the International Flight Attendants Association}

Passengers were not the only group concerned about secondhand smoke in the cabin. An SAS poll of flight attendants in 1980 found that smoke bothered $95 \%$ of all flight attendants (69\% to "a great extent" and $26 \%$ to a "certain extent"). Finnair representatives reported to Pottorff that "smoke accumulation in the back of DC 10's [sic] has been given as a reason their flight attendants don't want to work in the aft cabin", and also that in response to complaints Finnair had "reconfigured the aft cabin galley and non-smoking areas on the Airbus in an effort to minimize the impact of ETS in the aft cabin". ${ }^{32}$

PM recognised the need to neutralise flight attendants' concerns and sought the help of flight attendant unions and associations in order to spread its IFAQ message. ${ }^{26}{ }^{36}$ Philip Morris had established a relationship with the International Flight Attendants Association (IFAA) in 1987, when PM agreed to be a sponsor of the IFAA 7th World Congress. PM's 1988 public relations plan included "convey[ing] the story of the broad issue of IFAQ and the minimal role of ETS at the IFAA Congress in October" ${ }^{26} \mathrm{PM}^{\prime}$ 's letter to IFAA president Peter Tronke outlining the terms of PM's sponsorship included stipulations that PM could provide an "independent" speaker to address a plenary session on the subject of IFAQ. ${ }^{37}$ That speaker, Dr Phillip Witorsch, a Tobacco Institute consultant the tobacco industry used around the world to support its positions on a variety of issues related to secondhand smoke, ${ }^{38} 39$ spoke of all of the possible factors affecting IFAQ and dismissed the importance of secondhand smoke as one of those factors. Witorsch ended by noting that the 1986 NAS study's recommendation to end smoking on all commercial flights seemed "unreasonable" and "inappropriate $^{\prime \prime}$ in view of available data. ${ }^{40}$ The IFAA granted PM a two hour IFAQ panel discussion at the 1989 World Congress featuring tobacco industry ETS/IFAQ/IAQ consultants Charles Caliendi, Larry Holcomb, and Gray Robertson. ${ }^{41-43}$ PM considered the relationship with IFAA valuable enough to sponsor at least three more conferences-in 1989, 1991, and 1993-usually providing funding ranging from CHF 50000 (\$37 000) in 1987 to CHF 80000 (\$60 000) in 1993. ${ }^{37} 44-46$

PM's relationship with the IFAA offered other opportunities to spread the industry message that smoking restrictions would do little to solve the problem of IFAQ. For

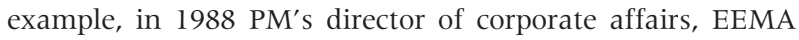
region, discussed drafting a letter IFAA president Peter Tronke could mail to heads of airline attendant unions and organisations with a copy of a Tobacco Institute sponsored paper "Impact of ETS on Cabin Air Quality" with "the letters individually typed for his signature on his letterhead" and "postage [put] on the envelopes, etc.," but, he warned, "PLEASE do not discuss such details in writing with Peter/ IFAA" (emphasis in original). ${ }^{3647} \mathrm{PM}$ also planned to "encourage IFAA president to participate, perhaps host, a panel discussion on airline workplace issues, of which smoking would be a minor part" ${ }^{26}$ In 1988 Tronke sent a letter to British Airways, at PM's request, urging the airline to 
do IFAQ studies; British Airways declined Tronke's offer of help. ${ }^{41} 48{ }^{49}$ A 1990 "PM EEC Corporate Affairs Agenda 199l" suggested using Tronke to lobby the German airline Lufthansa. $^{50}$

The documents do not reveal any direct payments to Tronke, but PM did budget money for IFAA in addition to the conference sponsorship-for example, a 1991 budget included under the heading "Special Projects" the item "IFAA \$25,000" ${ }^{51}$ A 1993 budget draft allocated IFAA $\$ 90000$ under the heading "Support for key third parties and programs". ${ }^{52}$ This $\$ 90000$ appears to be about $\$ 30000$ more than PM contributed to support the 1993 IFAA Congress. The documents did not reveal the purpose of the additional funds.

PM saw its relationship with the IFAA as a means to add legitimacy for the planned IFAQ study, which PM sought to fund and publish without exposing industry involvement. In a March 1987 memo to PM Europe public affairs and R\&D executives, PM's director of corporate affairs, EEMA Region, heralded the possibility of "negotiating a sponsorship agreement by which IFAQ studies could be funded through and published in the name of the IFAA", perhaps in order to gain legitimacy for the results. The final agreement between PM and IFAA, spelled out in a June 1987 letter to IFAA president Peter Tronke, specified that IFAA would "endeavor to have a report on such study published in scientific, medical and airline journals...". ${ }^{37} 53$

\section{Industry control}

PM later abandoned the idea of publishing IFAQ study results via the IFAA, perhaps because the creation of the Center for Indoor Air Research (CIAR) by US tobacco companies in 1988 provided PM with a better mechanism for controlling such studies while obscuring industry involvement. The CIAR, while funding some independent peer reviewed research, was used as a means for paying for work that met the industry's political, legal, and regulatory needs while maintaining the fiction that it was independent of the tobacco industry. ${ }^{39}{ }^{54-58}$ PM eventually opted to have CIAR officially fund the SAS study so that CIAR could "correctly be named as a sponsor" of the study and thereby "diminish the effectiveness of Antis [anti-smoking] PR efforts to challenge the credibility of the research". ${ }^{29} 36$ Efforts to obscure the study's origins suggests concern that public knowledge of industry participation might expose the research to criticism.

In addition to funding its portion of the IFAQ study through CIAR, PM sought other ways to obscure industry participation in the SAS IFAQ study. Final plans called for "ETS whitecoats" to publish the study in airline trade press and scientific and medical journals. ${ }^{29} 36$ ("Whitecoats" were "independent" scientists PM hired to conduct research intended to dispel concerns about the health risks of SHS as part of the industry's secret "International ETS Consultancy Project". ${ }^{57} 59$ ) As a June 1988 memo by Pottorff and Stig Carlson, director, corporate affairs, PM EEMA, noted, industry law firm Covington \& Burling's John Rupp (who managed industry scientific and regulatory responses to secondhand smoke worldwide, including the International ETS Consultancy Project ${ }^{39}{ }^{59}$ ) was responsible for "coordinating the selection and use" of scientists to undertake the study.$^{30}$ Rupp oversaw the selection of toxicologist Torbjorn Malmfors, statistician Daniel Thorburn, and occupation hygienist Arne Westlin, all three of whom were already working for PM as Nordic ETS consultants. ${ }^{306061}$ In fact, Malmfors, "Chief Expert" PM ETS consultant in the Nordic countries, had helped form and direct the EGIL group (Swedish acronym for the tobacco industry's "Expert Group for Indoor Air") in 1987.62 ${ }^{63}$ As in other parts of the world, ${ }^{39} 5859$ Covington \& Burling coordinated the consultants because PM recognised that, in general, ETS consultants should not appear to be working directly for the tobacco industry. ${ }^{18}$ The independence was illusionary; CIAR's draft budget for the project indicated that CIAR paid all three scientists for their participation in the SAS study, ${ }^{64}$ though their status as PM ETS consultants was never disclosed.

Aided by the ETS "whitecoats" who eventually published the study, as well as by other industry scientists, PM employees designed a study to examine the air quality in passenger cabins of DC- 9 and MD-80 aircraft on 48 representative flights. ${ }^{60}{ }^{63}$ RJ Reynolds' Guy Oldaker, for example, assisted with the statistical methods. ${ }^{65}$ Oldaker attended an August 1988 meeting to review the study design, wherein the participants "proceeded to go through the [proposed project design], asking questions, making comments and suggesting changes" ${ }^{66}{ }^{6}$ PM's Pottorff and Helmut Gaisch, industry IAQ consultant Charles Caliendi, Lorillard's V Norman, Covington \& Burling's Rupp, and the three PM ETS consultants also attended the planning meeting. ${ }^{66}$ The study proposed to measure the following: respirable suspended particles (RSP), nicotine, carbon monoxide, and carbon dioxide.

PM chose an outside laboratory, the Netherlands Organization for Applied Scientific Research or Nederlandse Organisatie voor Toegepast-Natuurwetenschappelijk Onderzoek (TNO) to collect data for the study, again in an attempt to cover industry involvement and provide legitimacy. "It's advisable," Pottorff and Carlson wrote in a 1988 memo, "to use government and semi governmental laboratories to conduct IFAQ research, as this factor will enhance the credibility of the research." ${ }^{\prime 30}$ According to Helmut Reif, director of science and technology, PM Europe, TNO could "carry out the IFAQ tests without tobacco industry fingerprints". ${ }^{30}{ }^{36}$ Nevertheless, PM's Reif was charged with carefully monitoring the scientific execution of the study, and Reif and his staff supervised TNO closely. ${ }^{48}{ }^{67}{ }^{68}$ According to Helmut Gaisch, PM employees coached "TNO scientifically from the earliest stages to the very last stages of the project" and "Reif and PM Senior Scientist Peter Martin have spent the last few weeks on de-bugging the TNO data and assisting TNO in making the basic statistical analysis of the results" ${ }^{69}$ TNO then turned the data over to CIAR, ${ }^{70}{ }^{71}$ where industry representatives could carefully control its presentation.

\section{Deleting information}

In addition to supervising $\mathrm{TNO}^{\prime} \mathrm{s}$ data collection, ${ }^{68}$ the industry exercised complete control over explanation and presentation of the results. As Gaisch wrote in a January 1989 status report: "The interpretation and the statistics are to be made by independent experts for the CIAR.,"71 Handwritten notes (author unknown) of a January 1989 meeting at the Washington DC offices of Covington \& Burling attended by RJ Reynolds, PM, Covington \& Burling, and EGIL, noted concerns about "inappropriate explanations" ${ }^{\prime \prime 2}$ in a draft of TNO's report that highlighted high levels of exposure to secondhand smoke, and indicated that TNO should delete this information before PM could deliver the results to SAS. ${ }^{6672} 73$ Pottorff stressed that it was CIAR's decision what went into TNO's report and noted that TNO had not been asked to draw conclusions and should concentrate instead on experimental techniques. Gaisch later wrote: "All chapters of the narrative part of TNO [report], going beyond the mere description of the experimental part, should be eliminated". ${ }^{71-73}$ The group designated CIAR executive director Max Eisenberg to approach TNO to request that the lab omit the material that concerned the industry. ${ }^{71} 72$

At CIAR's request, TNO removed an entire 21 page section entitled "Analysis of the results." Among the information deleted were the following conclusions ${ }^{74}{ }^{75}$ : 
- Nicotine concentrations of $10 \mu \mathrm{g} / \mathrm{m} 3$ were measured in the smoking sections, the tourist non-smoking section, and the two rows in front of the smoking section in the business class. In the two rows of the tourist non-smoking section in the front of a smoking section ("worst cases") nicotine concentrations of more than $40 \mu \mathrm{g} / \mathrm{m} 3$ were measured.

- The respirable dust concentrations often exceeded the World Health Organization guideline of $70 \mu \mathrm{g} / \mathrm{m}^{3}$ for PM 10 particulate matter. The probability of this was about $30 \%$ in the business non-smoking section and about $95 \%$ in the other sections.

- The carbon dioxide $\left(\mathrm{CO}_{2}\right)$ concentrations in the various sections did not differ significantly. The $\mathrm{CO}_{2}$ concentrations measured in the cabin were higher than the concentrations calculated from the data on the ventilation and the numbers of passengers in the cabin.

- The cumulative frequency distribution of the ETS components nicotine, respirable dust, and carbon monoxide were close to each other in the two smoking sections and in the tourist non-smoking section.

In addition, a table summarising the results was also deleted entirely from the executive summary, together with the following statement ${ }^{74}$ :

- The results for the environmental tobacco smoke (ETS) components, nicotine, respirable dust and $\mathrm{CO}_{2}$ indicate that substantial longitudinal transport of cabin air takes place. Relatively high nicotine concentrations of $10 \mu \mathrm{g} / \mathrm{m}^{3}$ or more were measured in the tourist non-smoking section and in the two rows of the business non-smoking in front of the smoking section.

- The $\mathrm{CO}_{2}$ concentrations were not significantly different in the different sections and were usually higher than calculated from the data on the ventilation system and the emission of the passengers. They often exceeded standards (1000 or $1200 \mathrm{ppm})$.

The industry in particular wanted TNO's conclusions about RSP and $\mathrm{CO}_{2}$ removed, ${ }^{72}{ }^{76} 77$ possibly because RSP levels are one of the most reliable indicators of and damaging components of secondhand smoke, and because the high $\mathrm{CO}_{2}$ levels may have been a result of the combustion process associated with smoking the cigarettes. The industry group considered the RSP levels "unexpectedly high"73 and decided to double check TNO's numbers, having another laboratory (International Technology Corporation) reanalyse the samples; International Technology Corporation confirmed TNO's results. ${ }^{71} 7378$

The excised data demonstrate that the simple separation of smokers from non-smokers in airplanes did not protect people in the non-smoking section from secondhand smoke. Indeed, TNO observed significant migration of secondhand smoke constituents into the tourist non-smoking section. The conclusions about $\mathrm{CO}_{2}$ concentrations also suggest that the aircraft ventilation systems were not adequate to deal with the combustion products put in the air by the burning cigarettes. Since SAS had already recognised the need to "improve the division between smokers and non-smokers", ${ }^{79}$ PM may have been sensitive to releasing data that underscored that need. The final report, ${ }^{75}$ when delivered to SAS, would not give a busy executive the clear view that smoking on airplanes presented a serious air quality problem on aircraft; the original version ${ }^{74}$ of the report, before it was revised by industry scientists and lawyers, would have.

\section{Misleading presentation of results}

In addition to managing and directing TNO's efforts, tobacco industry interests also carefully controlled the report written and published by "ETS whitecoats" Malmfors, Thorburn, and Westlin. On 16 March 1989, Mary Pottorff circulated a draft version of the SAS study to senior industry scientists $C R$ Green and Guy Oldaker (RJ Reynolds), Tom Osdene (PM), A Spears (Lorillard), and Covington \& Burlings's Rupp. ${ }^{80}$ On 21 March 1989, the same group, plus the study's authors and representatives from British American Tobacco and the Nordic National Tobacco Manufacturers Association, met in Stockholm to discuss the study further. ${ }^{81}$ After the March meeting in Stockholm, CIAR's Eisenberg forwarded another draft of the study to the same group, asking for comments by 5 April. ${ }^{82}$ That further drafts were circulated is evident from comments on the draft received from Green and Spears in June. Industry lawyers, as well as industry scientists, participated in the revisions. A 30 May 1989 bill to CIAR from Covington \& Burling contained charges for "continued work in connection with the SAS project, including consulting with Professor Malmfors and others in Washington and Stockholm concerning their research report, consulting with the Executive Director and Company scientists concerning the draft report and related matters, and editing the draft report...". ${ }^{83}$

A substantial difference existed between the published IFAQ study results paper "Air Quality in Passenger Cabins of DC-9 and MD-80 Aircraft" ${ }^{84}$ published under Malmfors' authorship in the journal Environmental Technology Letters in 1989, and the draft report TNO had produced. ${ }^{74}$ While the TNO draft reported standard deviations and full ranges for recorded values (reproduced in fig 1), Malmfors et al reported standard errors of the mean and 5\%/95\% range in separate tables (reproduced in fig 2 and 3). This presentation, while not wrong, is misleading, since a casual reader would probably underestimate the range of exposures. The presentation in Malmfors et al is unusual, since the original presentation in the TNO report provides more information in a more compact and clearer form and is a more common way of reporting such information; compare fig 1 with fig 2 and 3 . This presentation is particularly important, since it is the maximum, not the mean, levels that are generally important for regulatory purposes. ${ }^{85}$

Another important difference in presentation existed between TNO's report and the published paper. The industry group that met at Covington \& Burling in January 1989 had suggested that Malmfors compare measured levels of secondhand smoke components with existing standards. Malmfors agreed to this approach. ${ }^{73}$ When the paper appeared, however, it contained a table (fig 4) that omitted RSPs on the grounds that no standard "for RSP resulting from ETS" existed. This statement ignored the fact that there were standards for RSPs in general, though not for ETS in particular. Indeed, material the industry had TNO delete from the original TNO report ${ }^{74}$ had noted that the measured values of RSP exceeded the WHO standard of $70 \mu \mathrm{g} / \mathrm{m}^{3} 95 \%$ of the time in all but the business non-smoking sections.

The final industry edited paper "Air Quality in Passenger Cabins of DC-9 and MD-80 Aircraft" ${ }^{\prime 4}$ published in the journal Environmental Technology Letters diverged not only from TNO's draft report but also from earlier drafts of the paper circulated within the industry. ${ }^{86}$ The industry was careful not only to see that the substance was presented in ways that met the industry's needs, but also was careful in the choice of words. For example, a section title was changed from "Levels of air contaminates" to "Levels of air components."

More significant, reporting of an important result changed considerably. TNO's results showed that secondhand smoke levels in the tourist non-smoking section, sandwiched between business and tourist smoking sections, were much closer to levels found in the smoking sections than in the business non-smoking section, located in the front of the 
Table 2 Concentrations pex section. Nicotine and respirable dust (RSP) in $\mathrm{Hg} / \mathrm{m}^{3} \mathrm{CO}$ and $\mathrm{CO}_{2}$ in ppm.

\begin{tabular}{|c|c|c|c|c|c|c|c|}
\hline Component & Section & $\mathbf{a}$ & GM & GSD & AM & STD & Range \\
\hline Nicotine & $\mathrm{B} / \mathrm{NS}$ & 47 & 3.85 & 2.72 & 6.66 & 9.11 & $0.4-50$ \\
\hline " & $B / S$ & 48 & 30.8 & 1.79 & 36.1 & 20.9 & $7-104$ \\
\hline$"$ & $T / N S$ & 48 & 19.0 & 1.87 & 22.8 & 13.9 & $5-64$ \\
\hline$"$ & $T / S$ & 47 & 24.3 & 1.94 & 29.3 & 17.2 & $5-73$ \\
\hline Respirable dust & $\mathrm{B} / \mathrm{NS}$ & 47 & 50 & 2.15 & 70 & 74 & $15-440$ \\
\hline$"$ & $B / S$ & 48 & 187 & 1.90 & 218 & 113 & $11-600$ \\
\hline$"$ & $\mathrm{~T} / \mathrm{NS}$ & 48 & 155 & 1.67 & 176 & 92 & $45-560$ \\
\hline$"$ & $T / S$ & 47 & 187 & 1.71 & 213 & 105 & $45-500$ \\
\hline co & B/NS & 45 & 0.40 & 2.46 & 0.55 & 2.46 & $0.1-1.5$ \\
\hline$"$ & $B / S$ & 47 & 0.92 & 1.62 & 1.03 & 0.50 & $0.3-2.5$ \\
\hline$"$ & T/NS & 46 & 0.76 & 1.73 & 0.86 & 0.44 & $0.1-2.5$ \\
\hline$"$ & $T / S$ & 45 & 0.97 & 1.53 & 1.05 & 0.41 & $0.3-2.2$ \\
\hline $\mathrm{CO}_{2}$ & $\mathrm{~B} / \mathrm{NS}$ & 45 & 1213 & 1.23 & 1239 & 254 & $700-2000$ \\
\hline$*$ & $B / S$ & 47 & 1200 & 1.27 & 1232 & 282 & $700-1950$ \\
\hline$"$ & $\mathrm{~T} / \mathrm{NS}$ & 46 & 1216 & 1.24 & 1244 & $2 \in 2$ & $650-1920$ \\
\hline$n$ & $T / s$ & 46 & 1357 & 1.24 & 1387 & 286 & $750-2100$ \\
\hline
\end{tabular}

Figure 1 Summary table of results included in the original report from $\mathrm{TNO}^{74}$ delivered to the tobacco industry. Note that the table presents the fact that levels of several components were high and presents the range of observations. plane. Malmfors' first draft stated: "Any such [health effects of SHS exposure] in the tourist non-smoking section would have been closer to those in the smoking sections." ${ }^{166}$ This statement was deleted from the published version of the paper. Instead, the published version noted "the levels of measured ETS-components in [the tourist nonsmoking section] is lower than in the smoking sections", 84 which, while true, was misleading. As clearly indicated in the original report, the levels in the non-smoking section were only slightly lower than in the smoking section.

A second significant change between the versions was in the study's attributions and acknowledgements. The draft paper reported that the CIAR had sponsored the study and had asked the authors "to give advice about the conduct of the study and to evaluate the results" ${ }^{16}$ That statement made explicit the relationship between the authors and CIAR. The
Table 3: Average level of air couponents by section

\begin{tabular}{|c|c|c|c|c|c|c|c|c|}
\hline \multirow[b]{3}{*}{$\operatorname{RSP}\left(\mu \mathrm{g} / \mathrm{m}^{3}\right)$} & \multicolumn{6}{|c|}{ Class and section } & \multirow{2}{*}{\multicolumn{2}{|c|}{ Is }} \\
\hline & BAS & & BS & & ThS & & & \\
\hline & 60 & (7) & 250 & (18) & 160 & (15) & 220 & (21) \\
\hline $\begin{array}{l}\text { WRP Average reading } \\
\text { (niV) }\end{array}$ & 0.6 & $(0.1)$ & 1.9 & $(0.1)$ & 1.3 & $(0.1)$ & 1.7 & $(0.2)$ \\
\hline $\begin{array}{l}\text { IRP Maximum reading } \\
\text { (m) }\end{array}$ & 4 & $(0.8)$ & 29 & $(4.4)$ & 7 & $(0.8)$ & 18 & $(3.2)$ \\
\hline Nicotine $\left(\mu \mathrm{g} / \mathrm{m}^{3}\right)$ & 5 & $(0.9)$ & 41 & $(3.6)$ & 21 & $\{2.5\}$ & 32 & $(3.5)$ \\
\hline $\begin{array}{l}\text { Concentration } \\
\text { of } \infty \text { (p pem) }\end{array}$ & 0.6 & $(0.06)$ & 1.1 & $(0.08)$ & 0.8 & $(0.07)$ & 1.1 & $(0.11)$ \\
\hline $\begin{array}{l}\text { Concentration } \\
\text { of } \mathrm{CO}_{2} \text { (pgin) }\end{array}$ & 1310 & $(41)$ & 1310 & (42) & 1270 & $(36)$ & 1430 & (36) \\
\hline $\begin{array}{l}\text { Mean Relative } \\
\text { Hunidity }(8)\end{array}$ & 25 & $(0.7)$ & 25 & $(0.8)$ & 25 & $(0.6)$ & 25 & $(1.0)$ \\
\hline
\end{tabular}

Figure 2 One element of the presentation of results in the paper published by Malmfors ${ }^{84}$; compare with the simpler and more compact presentation in fig 1. Note that the standard deviations have been replaced with the standard errors of the mean. 
Table 4: Ranges in the levels of air components between flights - Business Non-Sroking (BNS), Dusiness Smoking (BS), Tourist Non-Smokiog (MNS) and Tourist Smoking (TS).

\begin{tabular}{|c|c|c|c|c|c|c|c|c|}
\hline & \multicolumn{2}{|c|}{ BNS } & \multicolumn{2}{|c|}{ BS } & \multicolumn{2}{|c|}{ TNS } & \multicolumn{2}{|c|}{ TS } \\
\hline & 58 & 958 & 58 & 953 & 58 & 958 & 58 & 958 \\
\hline RSP $\left(\mu g / m^{3}\right)$ & 12 & 180 & 93 & 540 & 50 & 400 & 65 & 560 \\
\hline TRP-Average & 0.1 & 2.0 & 0.5 & 5.1 & 0.4 & 3.6 & 0.3 & 5.5 \\
\hline TRP-Maximum & 0.6 & 14 & 4 & 110 & 1.8 & 20 & 2.3 & 69 \\
\hline Nicotine $\left(\mu \mathrm{g} / \mathrm{m}^{3}\right)$ & 0.8 & 17 & 13 & 98 & 4.8 & 62.1 & 15 & 98 \\
\hline $\begin{array}{l}\text { Concentration } \\
\text { of } c 0 \quad \text { (ppom) }\end{array}$ & 0.1 & 2.2 & 0.4 & 2.7 & 0.3 & 2.1 & 0.4 & 2.5 \\
\hline $\begin{array}{l}\text { Concentration } \\
\text { of } \mathrm{\infty}_{2} \quad \text { (ppon) }\end{array}$ & 900 & 1840 & 850 & 1930 & 860 & 1810 & 1020 & 1950 \\
\hline $\begin{array}{l}\text { Mean Relative } \\
\text { Humidity (8) }\end{array}$ & 17 & 34 & 16 & 36 & 17 & 34 & 15 & 38 \\
\hline
\end{tabular}

This table shows estimated quantities. For example 5\% of the passengers in BNS mere exposed to less than $12 \mu \mathrm{g} / \mathrm{m}^{3} \mathrm{RSP}$, and 95\% of the passengers in the same section were exposed to less than $180 \mu \mathrm{g} / \mathrm{m}^{3} \mathrm{RSP}$.

Figure 3 One element of the presentation of results in the paper published by Malmfors ${ }^{84}$; compare with the simpler and more compact presentation in fig 1 . Note that the range has been replaced with the $5 \%$ and $95 \%$ points.

published version stated simply: "The authors have served as consultants to CIAR." ${ }^{84}$ This carefully worded statement suggests that the authors had, in the past, worked with CIAR, and not that they were paid by CIAR to interpret and publish the present study. There was no mention of the role of the industry lawyers or scientists in the development and conduct of the study, much less the writing of the report and paper.
Since CIAR involvement in the study might raise questions of bias, PM attempted to deflect queries about the study's origins. PM provided SAS with answers to questions airline management was likely to receive when announcing completion of the study. ${ }^{87}$ If asked who sponsored the research, for example, SAS was told to respond, CIAR, "an American-based non-profit group which sponsors research of different kinds regarding the indoor environment". If asked

Table 7: Air quality standards

\begin{tabular}{|c|c|c|c|}
\hline & Value & Time period & Source \\
\hline \multicolumn{4}{|c|}{ INDOOR AIR IN GENERAL } \\
\hline Nicotine & $500 \mu \mathrm{g} / \mathrm{m}^{3}$ & 8 hrs & OSHA US \\
\hline Carbon monoxide & $\begin{array}{r}50 \mathrm{ppm} \\
35 \mathrm{pqm} \\
35 \mathrm{ppm} \\
9 \mathrm{ppm}\end{array}$ & $\begin{array}{l}8 \mathrm{hrs} \\
8 \mathrm{hrs} \\
1 \mathrm{hr} \\
8 \mathrm{hrs}\end{array}$ & $\begin{array}{l}\text { OSHA US } \\
\text { ASS SWEDEN } \\
\text { BPA US } \\
\text { BPA US, WHO }\end{array}$ \\
\hline Carbon dioxide & $\begin{array}{l}5000 \mathrm{ppm} \\
1000 \mathrm{ppm}\end{array}$ & $\begin{array}{l}8 \mathrm{hrs} \\
8 \mathrm{hrs}\end{array}$ & $\begin{array}{l}\text { OSHA LS } \\
\text { ASERAE, JAPAN }\end{array}$ \\
\hline \multicolumn{4}{|c|}{ AIRLINE CABIN AIR } \\
\hline Carbon monoxide & 50 ppm & & FAA US \\
\hline Carbon dioxide & $30000 \mathrm{ppm}$ & & FAA US \\
\hline \multicolumn{4}{|c|}{$\begin{array}{l}\text { OSHA - Occupational Safety and Health Adninistration } \\
\text { ASS - Workers Protection Board } \\
\text { EPA - Enviromental Protection Agency } \\
\text { ASHRAE - Anerican Society of Heating, Refrigeration and Air Concitioning Engineers } \\
\text { FAA - Federal Aviation Adninistration }\end{array}$} \\
\hline
\end{tabular}

Figure 4 Presentation of international standards in paper published by Malmfors. ${ }^{84}$ Note that the standards for particulates, which had been stressed in the original TNO report, ${ }^{74}$ have been dropped. 
about tobacco company involvement, the suggested response was "We understand that CIAR receives grants from various sources, including some from the tobacco industry". If tobacco money is involved, how can research be unbiased? "The results were analyzed by three independent Swedish scientists" and published in a peer-reviewed journal so "the scientific integrity of the research is beyond reasonable question" ${ }^{87}$ Nowhere is it noted that the "three independent Swedish scientists" were also part of the tobacco industry's International ETS Consultants project. ${ }^{59}{ }^{62}$

The illusion of independence was important, since the authors promoted industry positions. Although both the abstract and the body of the paper specified that "no observation of health effects were made", the study contained a lengthy discussion of health consequences, concluding that long term health effects of exposure to secondhand smoke on airplanes "were most likely insignificant in passengers and cabin crew with or without compromising medical conditions" ${ }^{84}$ There were no data presented in the paper to support this statement. The authors also emphasised the effectiveness of the aircraft ventilation systems, though the paper provided no data demonstrating that ventilation systems could reduce the levels of smoke pollutants to levels deemed acceptable by international health authorities such as the WHO ${ }^{84}$ Indeed, the results on $\mathrm{CO}_{2}$ in the original TNO report $^{74}$ indicated that the ventilation system was not adequate to control the combustion products from burning cigarettes. Malmfors dismissed this observation by speculating that the ventilation system "airflows, which have not been measured, are lower than intended" (emphasis added). He seemed not to consider the possibility that the ventilation system was being operated according to specification and was simply not adequate to control the levels of combustion products put into the air by burning cigarettes. Disregarding results that clearly showed secondhand smoke polluting the cabin, the paper instead pushes industry positions.

\section{IFAQ study did not stop smoke-free policies in Scandinavia}

In spite of initial enthusiasm for IFAQ studies as a means of forestalling smoking restrictions, ${ }^{18} \mathrm{PM}$ and the rest of the industry cooled on the idea after completion of the SAS study. The dampened interest may or may not be attributable to the fact that, on the recommendation of the Nordic Council, an interparliamentary body charged with developing cooperation between Scandinavian nations, both SAS and Finnair ended smoking on all Nordic area flights effective l November 1989, just a few months after publication of the SAS study. News that SAS planned to host a meeting of airlines servicing the Nordic countries in an effort to have them adopt smoke-free policies ${ }^{42}{ }^{88}$ may have discouraged further studies. A more obvious explanation is that the SAS study failed to support $\mathrm{PM}^{\prime}$ s position that "most seats in no-smoking sections are untouched by ETS" and that "ventilation systems in aircraft are extremely efficient". ${ }^{27}$

\section{Smoking continued on SAS outside of the Nordic region}

Although SAS implemented smoking restrictions within Scandinavia, smoking continued on SAS flights to the rest of Europe and beyond. When SAS extended its smoke-free flight policy to cover all of Europe in March 1993, ${ }^{89}$ PM reacted vigorously, applying some of the other tactics the industry deployed to resist smoking restrictions. These tactics included applying economic pressure by boycotting SAS and by attempting to create a stir in the Danish investor community (SAS is listed on the Danish stock exchange); issuing press releases and articles calling bans "discrimination"; and mobilising Scandinavian and international smokers' rights groups. ${ }^{90}$ A Norwegian news item two months later, Ban on smoking goes up in smoke", ${ }^{91}$ reported that SAS had rescinded the expanded restrictions because "antismokers protest[ed]". Although SAS denied that pressure from the tobacco industry precipitated the turnaround, PM's Matthew Winokur, manager for worldwide regulatory affairs for PM Europe, took credit for the turnaround in a July 1993 memo to senior vice president for corporate affairs Craig Fuller. "We have had mixed results combating [voluntary smoke-free policies]. However, success is possible. SAS recently overturned its decision to ban smoking on longer flights."

SAS went entirely smoke-free in 1997. According to an SAS press release: "We have chosen to introduce non-smoking in stages and our customer surveys show that an overwhelming majority prefer a totally smoke-free environment on board. Our surveys also show that as many as 60 percent of our passengers who smoke accept the introduction of a nonsmoking policy." ${ }^{\prime 93}$

\section{DISCUSSION}

This story of the IFAQ study follows the now familiar pattern of the tobacco industry working in the shadows to fund and control studies designed and presented in a way to support industry positions on secondhand smoke. As with other secondhand smoke related issues, industry lawyers, scientists, and consultants cooperated to produce "studies" that appeared to be legitimate, unbiased scientific research but which were controlled by industry at all levels. ${ }^{54-569495}$ For example, the industry generated a study to counter findings that showed an association between lung cancer and exposure to secondhand smoke. ${ }^{94}$ As in the SAS IFAQ study, several participants, including an industry scientist as well as a representative of Covington and Burling, were unacknowledged.

PM conceived of IFAQ studies as part of an overall strategy to "reverse scientific and popular opinion that ETS is harmful to health" and restore the "social acceptability of smoking". ${ }^{27}$ IFAQ studies were to provide a means for spreading the industry's message that secondhand smoke was an insignificant factor in air quality onboard aircraft. ${ }^{19}$ Tobacco industry funded IFAQ studies, like those funded by governments and non-governmental organisations, clearly showed that secondhand smoke polluted aircraft in which smoking was permitted.$^{85}$ Four industry funded studies (including the SAS study) yielded similar concentrations of contaminants as did government and airline sponsored studies but offered different conclusions. ${ }^{85}$ In the SAS example, the industry chose to disregard the study's implications and focused instead on propagating its message that secondhand smoke on airplanes posed no health risk to passengers and crew and that adequate ventilation would alleviate problems perceived to be created by secondhand smoke.

The industry also avoided comparing RSP and other secondhand smoke components with values collected on flights during which smoking was not permitted, despite suggestions from its own employees to do so. ${ }^{96}$ Indeed, other studies done by non-industry sources demonstrated that RSPs in smoke-free airliner cabins were generally below $10 \mu \mathrm{g} / \mathrm{m}^{3},{ }^{85}$ well below those observed when smoking was present and well within accepted standards of exposure. ${ }^{84}$ 97-99

Sponsoring IAFQ studies was but one of several delaying tactics the industry employed in its efforts to reverse or delay implementation of in-flight smoking restrictions. For example, the industry fought smoking restrictions at the legislative and regulatory levels, ${ }^{100-105}$ pressured individual airlines that instituted restrictions, ${ }^{90}{ }^{106-108}$ and generated letter writing 


\section{What this paper adds}

The tobacco industry has used consultants and other third parties to mask involvement in second hand smoke studies and to argue that ventilation is a solution to problems posed by secondhand smoke.

The industry used an identical strategy to fight airline smoking regulations. Industry lawyers and scientists edited report results to downplay the health risks of secondhand smoke. The authorship disclosures did not describe fully the level of industry involvement in designing, executing, and interpreting the results. This case adds to the growing body of evidence that no scientific studies associated with the tobacco industry can be taken at face value.

campaigns from "consumers" protesting proposed or actual restrictions. ${ }^{109-114}$ Overall, industry tactics helped slow implementation of no smoking policies: SAS and many other airlines permitted smoking for almost 20 years after activists first called for eliminating the practice. As a result, airline patrons and employees, particularly flight attendants, continued to be exposed to levels of pollution from secondhand smoke, particularly particulates, that the industry's own consultants had noted exceeded international standards in the late 1980s.

\section{ACKNOWLEDGEMENTS}

This work was supported by NCI grant CA-87472 and the American Legacy Foundation.

\section{Authors' affiliations}

K Neilsen, S A Glantz, Kalmanovitz Library and Center for Tobacco Control Research and Education, University of California, San Francisco, San Francisco, California, USA

\section{REFERENCES}

1 Kluger R. Ashes to ashes: America's hundred-year cigarette war, the public health, and the unabashed triumph of Philip Morris. New York: Vintage, 1997.

2 Tobacco org. Tobacco timeline: the Twentieth century 1950-1999-the battle is joined. http://www.tobacco.org/resources/history/Tobacco_History202.html. Accessed 24 May 2003

3 Action on Smoking and Health. Introduction to ASH. 2003: Accessed May 24, 2003. http://ash.org/about/.

4 Nosmoke. org. Smokefree Transportation Chronology. 21 August 2002. http://www.no-smoke.org/transportchron.html. Accessed September 24 2003.

5 Borio G. Tobacco Timeline. The Twentieth Century, 1950-1999-The Battle is Joined. 2001. http://www.tobacco.org/resources/history/ Tobacco_History20-2.html. Accessed September 24, 2003.

6 Grefe EA. In Requesting Comments on Smoking in Airplanes, the CAB Has Given Us a Wedge through Which We Should Drive a Tank. December 14, 1976 RJ Reynolds: Bates No. 503686570/6571. http:// legacy.library.ucsf.edu/tid/urn85d00. Accessed May 25, 2003.

7 Sample Letter August, 1983 Philip Morris. Bates No. 2044207569. http:// legacy.library.ucsf.edu/tid/clp55e00. Accessed May 25, 2003.

8 Grefe EA. Preliminary Test Results of Petition Drive. December 31, 1976 Philip Morris. Bates No. 2025014948/4950. http:// legacy.library.ucsf.edu/tid/sdg24e00. Accessed May 25, 2003.

9 Hobbs WD. January 19, 1977 RJ Reynolds. Bates No. 502203609/3609 http://legacy.library.ucsf.edu/tid/amu19d00. Accessed May 25, 2003

10 Kloepfer WJ. Special Report-CAB Petition Project. Tobacco Institute; January 25, 1977 Philip Morris: Bates No. 2025014794/4797. http:// legacy.library.ucsf.edu/tid/odg24e00. Accessed May 25, 2003.

11 Kloepfer W. January 21, 1977 Tobacco Institute: Bates No. TIMN0120658/ 0659.Minnesota AG. http://legacy.library.ucsf.edu/tid/fwg92fo0. Accessed May 25, 2003.

12 Hirayama T. Non-smoking wives of heavy smokers have a higher risk of lung cancer: a study from Japan. BMJ 1981;282:183-5.

13 Ong E, Glantz SA. Hirayama's work has stood the test of time. Bull WHO 2000;78:938-9.

14 US Department of Health and Human Services. The health consequences of involuntary smoking. A report of the Surgeon General, 1986. Rockville,
Maryland: Public Health Service, Centers for Disease Control, 1986. (DHHS Publication No (CDC) 87-8398.)

15 Committee on Passive Smoking NRC. Environmental tobacco smoke: measuring exposures and assessing health effects. Washington DC: National Academy Press, 1986.

16 National Research Council (US). Committee on Airliner Cabin Air Quality. The airliner cabin environment: air quality and safety. Washington DC: National Academy Press, 1986.

17 US Department of Transportation. Report to Congress. Airline Cabin Air Quality Report to the Department of Transportation to the United States Congress Pursuant to Public Law 98-466. February, 1987: Bates No. TI1 1 153039/3078. http://legacy.library.ucsf.edu/tid/qmh40c00 Accessed September 24, 2003.

18 Philip Morris. An Action Plan for ETS in Europe and Adjacent Areas, 890000-920000. August 10, 1988 Philip Morris: Bates No. 2501046476/ 6488. http://legacy.library.ucsf.edu/tid/sev32e00. Accessed May 23, 2003.

19 Drope J, Bialous SA, Glantz SA. Tobacco industry efforts to present ventilation as an alternative to smoke-free environments in North America. Tobacco Control 2004;13(suppl I):i41-7.

20 Bialous SA, Glantz SA. ASHRAE Standard 62: tobacco industry's influence over national ventilation standards. Tobacco Control 2002;11:315-28.

21 Traynor MP, Begay ME, Glantz SA. New tobacco industry strategy to prevent local tobacco control. JAMA 1993;270:479-86.

22 Samuels B, Glantz SA. The politics of local tobacco control. JAMA 1991;266:2110-7.

23 Dearlove JV, Bialous SA, Glantz SA. Tobacco industry manipulation of the hospitality industry to maintain smoking in public places. Tobacco Control 2002;11:94-104

24 Dearlove JV, Glantz SA. Boards of health as venues for clean indoor air policy making. Am J Public Health 2002;92:257-65.

25 Powers $\mathrm{CH}$. Talking points on smoking aboard airliners for Charles $\mathrm{H}$ Powers before the Executive Committee. April 6, 1989 Tobacco Institute: Bates No. TIDN0010324/0332. dunn. http://legacy.library.ucsf.edu/tid/gmk91f00. Accessed May 25, 2003

26 Appendix E Outline public relations programme for dealing with the ETS issue in the airline industry. April, 1988 Philip Morris: Bates No. 2501045178/5203. http://legacy.library.ucsf.edu/tid/fnx19e00. Accessed May 23, 2003

27 Airline Smoking Presentation at Nordic NMA ETS Working Group Helsinki, 871210. December 9, 1987 Philip Morris: Bates No. 2501330521/0536 http://legacy.library.ucsf.edu/tid/cje32e00. Accessed May 23, 2003.

28 Kannangara A. PM EEMA Region: 870000 ETS Plan. March 9, 1987 Philip Morris: Bates No. $2501152320 / 2332$. http://legacy.library.ucsf.edu/tid/ yik49e00. Accessed May 23, 2003.

29 Carlson SG. In flight air quality tests (IFAQ) on Nordic-Based Airlines. May 4, 1988 Philip Morris: Bates No. 2501458517/8519. http:// legacy.library.ucsf.edu/tid/gxp39e00

30 Carlson SG, Pottorff M. In Flight Air Quality Tests (IFAQ) on Nordic-Based Airlines. June 30, 1988 Philip Morris: Accessed May 23, 2003. Bates No. 2501042537/2541.. http://legacy.library.ucsf.edu/tid/guh22e00

31 Pottorff M. Notes to File. SAS Meeting - 16 June 1988. July 05, 1988 RJ Reynolds: Accessed May 25, 2003. Bates No. 508220210/0214. http:// legacy.library.ucsf.edu/tid/yms31d00. Accessed May 23, 2003.

32 Pottorff M. Meeting with Finnair-880627. July 5, 1988 Philip Morris: Bates No. 2501042529/2530. http://legacy.library.ucsf.edu/tid/buh22e00 Accessed May 25, 2003.

33 Gronlund JE. No-Smoking Oslo-Stockholm V.V. 830900. SAS; October, 1983 Philip Morris: Bates No. 2501330730/0796. http:// legacy.library.ucsf.edu/tid/zxx29e00. Accessed May 23, 2003.

34 Philip Morris. Inflight Survey on Smoking No-Smoking STO-OSL V.V 811200. SAS; January 15, 1981 Philip Morris: Bates No. 2501330802/ 0824. http://legacy.library.ucsf.edu/tid/uxx29e00. Accessed May 25, 2003.

35 Dahlgren S. Scandinavian Airlines System August 1, 1988 Philip Morris: Bates No. 2501042670. http://legacy.library.ucsf.edu/tid/ijh22e00. Accessed May 23, 2003.

36 SAS Scanair and Finnair: In-flight air quality tests. June 21, 1988 Philip Morris: Bates No. 2501042759/2760. http://legacy.library.ucsf.edu/tid/ ujh22e00. Accessed May 23, 2003.

37 Dulles FH. July 03, 1987 Philip Morris: Bates No. 2023540424/0425 http://legacy library.ucsf.edu/tid/jiu78e00. Accessed May 23, 2003.

38 Glantz SA, Slade J, Bero LA, Hanauer PDEB. The cigarette papers. Berkeley, California: University of California Press, 1996

39 Barnoya J, Glantz SA. Tobacco industry success in preventing regulation of secondhand smoke in Latin America: the "Latin Project". Tobacco Control 2002;11:305-14.

40 Philip Morris. Summary of Presentation of Philip Witorsch, M.D. To 7th World Congress of International Flight Attendants Association, Zurich, Switzerland. October 19, 1987 Philip Morris: Bates No. 2501331029/ 1033. http://legacy.library.ucsf.edu/tid/rwx29e00. Accessed May 23 2003.

41 Tronke PA. October 18, 1988 Philip Morris: Bates No. $2501458483 / 8484$. http://legacy.library.ucsf.edu/tid/ixp39e00. Accessed May 25, 2003.

42 Farnel FJ. EEMA Regional Annual Report Regarding PMI Corporate Affairs Action Plan. October 16, 1989 Philip Morris: Bates No. 2500019962/ 9976. http://legacy.library.ucsf.edu/tid/mli42e00. Accessed May 23, 2003.

43 Surveys and Position Papers. February 15, 1989 Philip Morris: Bates No. 2501342247/2251. http://legacy.library.ucsf.edu/tid/jyu39e00. Accessed May 23, 2003. 
44 Clark M, Maglione P. IFAA. February 20, 1989 Philip Morris: Bates No. 2501458478. http://legacy.library.ucsf.edu/tid//xp39e00. Accessed May 23, 2003.

45 Okoniewski A. IFAA Annual Congress. September 16, 1993 Philip Morris: Bates No. 2024206846.http://legacy.library.ucsf.edu/tid/rln46e00. Accessed May 23, 2003.

46 ETS-Transportation. 1991 Philip Morris: Bates No. 2501456409. http:// legacy.library.ucsf.edu/tid/cgr22e00. Accessed May 23, 2003.

47 Oxberry D. Tronke British Airways. October 6, 1988 Philip Morris: Bates No. 2501458504B/8505. http://legacy.library.ucsf.edu/tid/tlu22e00. Accessed May 23, 2003.

48 Pottorff M. Meeting at TNO-880628. July 5, 1988 Philip Morris: Bates No. 2023541231/1232. http://legacy.library.ucsf.edu/tid/aiu78e00. Accessed May 25, 2003.

49 Pottorff M. Meeting with Peter Tronke, Airport Amsterdam-000629. July 5, 1988 Philip Morris: Bates No. 2023529561. http://legacy.library.ucsf.edu/ $\mathrm{tid} / \mathrm{tfo} 34 \mathrm{e} 00$. Accessed May 25, 2003.

50 PM EEC Corporate Affairs Agenda for 910000. Philip Morris; September 3, 1990 Philip Morris: Bates No. 2500014889/4922. http:// legacy.library.ucsf.edu/tid/lai42e00. Accessed May 23, 2003

51 Backup. October 11, 1991 Philip Morris: Bates No. 2071027379/ 7380.http://legacy.library.ucsf.edu/tid/qbl16c00. Accessed May 23, 2003

52 Philip Morris. September, 1993 Philip Morris: Bates No. 2045655955/ 5956.http://legacy.library.ucsf.edu/tid/ttr52e00. Accessed May 23, 2003.

53 Robinson JB. IFAA - International Flight Attendants Association. March 29, 1987 Philip Morris: Bates No. 2023540421/0422. http:// legacy.library.ucsf.edu/tid/iun34e00. Accessed May 25, 2003.

54 Barnes DE, Bero LA. Industry-funded research and conflict of interest: an analysis of research sponsored by the tobacco industry through the Center for Indoor Air Research. J Health Polit Policy Law 1996;21:515-42.

55 Barnes DE, Bero LA. Scientific quality of original research articles on environmental tobacco smoke. Tobacco Control 1997;6:19-26.

56 Bero L, Barnes D, Hanaver P, et al. Lawyer control of the tobacco industry's external research program. JAMA 1995;274:241-7.

57 Drope J, Chapman S. Tobacco Industry efforts at discrediting scientific knowledge of environmental tobacco smoke: a review of internal industry documents. J Epidemiol Community Health 2001;55:588-94.

58 Muggli M, Forster JL, Hurt R Jr. The smoke you don't see: uncovering tobacco industry scientific strategies aimed against environmental tobacco smoke policies. Am J Public Health 2001;91:1419-23.

59 Muggli ME, Hurt RD, Blanke D. Science for hire: A tobacco industry strategy to influence public opinion on secondhand smoke. Nicotine Tobacco Res 2003;5:303-14

60 Gaisch H. ETS Plan and Budget for the Years 880000, 890000, 900000 and 910000 PME S\&T Neuchatel Coverage: PME EEC \& EEMA Region Theme: ETS in the Context of Air Quality. April 19, 1988 Philip Morris: Bates No. 2501152297/2300. http://legacy.library.ucsf.edu/tid/ugh22e00. Accessed May 23, 2003.

61 Pottorff M. In-Flight Testing-European Airlines. July 5, 1988 Philip Morris: Bates No. 2501042534/2535. http://legacy.library.ucsf.edu/tid/ euh22e00. Accessed May 25, 2003.

62 Gaisch H. ETS Plan and Budget for the Years $880000,890000,900000$ and 910000. April 19, 1988 Philip Morris: Bates No. 2028364436/4439. http://legacy.library.ucsf.edu/tid/sah56e00. Accessed May 23, 2003.

63 Rupp JP. Covington Burling; April 2, 1987 Philip Morris: Bates No. 2023543320/3321.http://legacy.library.ucsf.edu/tid/kan87e00. Accessed May 25, 2003.

64 Lorillard. Proposed Budget. August, 1988 Lorillard: Bates No. 87311903/ 1904. http://legacy.library.ucsf.edu/tid/yuk1 le00. Accessed May 23 2003

65 Oldaker G. Statistical Tasks in Connection with Scandinavian Airlines System (SAS) Project. October 11, 1988 RJ Reynolds: Bates No. 508220001/0003. http://legacy.library.ucsf.edu/tid/xue04d00. Accessed May 23, 2003

66 Norman V. SAS ETS Study, Preliminary Meeting in Stockholm. September 7, 1988 Lorillard: Bates No. 87774866/4870. http://legacy.library.ucsf.edu/ $\mathrm{tid} / \mathrm{tdp} 21 \mathrm{e} 00$. Accessed May 26, 2003.

67 Gaisch H. CIAR: TNO SAS Study. August 26, 1988 Philip Morris: Bates No. 2023529649. http://legacy.library.ucsf.edu/tid/pbt78e00. Accessed May 23, 2003

68 Corporate Affairs Support Requirements Needed from S\&T and R\&D in 880000. 1988 Philip Morris: Bates No. 2501474267/4270. http:// legacy.library.ucsf.edu/tid/uqh22e00. Accessed May 23, 2003.

69 Gaisch HW. Meeting BAT RJR PM. December 21, 1988 Philip Morris: Bates No. 2501042601/2602. http://legacy.library.ucsf.edu/tid/ejh22e00. Accessed May 23, 2003

70 Gaisch HW. SAS IFAQ Study. December 12, 1988 Philip Morris: Bates No. 2501254941. http://legacy.library.ucsf.edu/tid/ouj32e00. Accessed May 23, 2003.

71 Gaisch HW. Monthly Report Highlight 890100. January 31, 1989 Philip Morris: Bates No. $2501152038 / 2052$. http://legacy.library.ucsf.edu/tid/ ifh22e00. Accessed May 23, 2003.

72 Philip Morris. [Handwritten Notes, 1/03/89]. January 3, 1989 Philip Morris: Bates No. 2023528894/8895. http://legacy.library.ucsf.edu/tid/ fdt78e00. Accessed May 23, 2003.

73 Martin P. PEN: 000102-000106. 1988 Philip Morris: Bates No. 2501255448. http://legacy.library.ucsf.edu/tid/gmj32e00. Accessed May 23, 2003.

74 Cornelissen HJM, Heidema LF, Hillebrand AJ, et al. 2nd Draft study of components in the environment of passenger cabins in SAS flights. CIAR;
TNO; December 16, 1988 Lorillard: Bates No. 89816304/6612. http:// legacy.library.ucsf.edu/tid/pub01e00. Accessed May 23, 2003.

75 Vanderwal JF. Study of components in the environment of passenger cabins in SAS flights. TNO; January 23, 1989 RJ Reynolds: Bates No. 506848666/ 8950. http://legacy.library.ucsf.edu/tid/kmp54d00. Accessed May 25, 2003.

76 Philip Morris. [Handwritten Notes 1/04/89]. Philip Morris; January 4, 1989: Bates No. 2023528896/8899. http://legacy.library.ucsf.edu/tid/ jfo34e00. Accessed May 26, 2003.

77 Philip Morris. Another storm in a teacup. December 16, 1988 Philip Morris: Bates No. 2501254939/4940. http://legacy.library.ucsf.edu/tid/ nuj32e00. Accessed September 24, 2003.

78 Erikson CA. We have completed the analyses for ultraviolet particulate matter (UV-PM) on the 214 filter samples received from CIAR on January 11 1989 (8901 11); Original certificates of analysis from the laboratory are enclosed. Intl, Technology, January 31, 1989 RJ Reynolds: Bates No. 507965470/5471. http://legacy.library.ucsf.edu/tid/tpb14d00. Accessed May 23, 2003.

79 Philip Morris. SAS improves smoking division. October 18, 1983 Philip Morris: Bates No. 2501330828. http://legacy.library.ucsf.edu/tid/ qxx29e00. Accessed May 23, 2003.

80 Pottorff M. SAS Study [Draft Report]. Philip Morris; March 16, 1989: Bates No. 2023528820. http://legacy.library.ucsf.edu/tid/ifo34e00. Accessed May 26, 2003

81 Philip Morris. Monthly activities. July 27, 1989 Philip Morris: Bates No. 2028364552/4554. http://legacy.library.ucsf.edu/tid/ezg56e00. Accessed September 24, 2003.

82 Eisenberg M. SAS Study. Center for indoor air research; March 27, 1989 Philip Morris: Bates No. 2023527212. http://legacy.library.ucsf.edu/tid/ mno34e00. Accessed May 23, 2003.

83 Rupp J. Covington Burling; May 30, 1989 Philip Morris: Bates No. 2023526960. http://legacy.library.ucsf.edu/tid/wys78e00. Accessed May 25, 2003.

84 Malmfors T, Thorburn D, Westlin A. Environmental technology letters. Air quality in passenger cabins of DC-9 and MD-80 aircraft. 1989 RJ Reynolds: Bates No. 507963763/3779. http://legacy.library.ucsf.edu/tid/ qus31d00. Accessed May 23, 2003.

85 Repace J. Flying the smoky skies: secondhand smoke exposure of flight attendants. Tobacco Control 2004;13(suppl I):i8-19.

86 Malmfors $T$, Thorburn D, Westlin A. [Draft] Air quality in passenger cabins during flights of DC-9 aircraft operated by SAS. March, 1989 Philip Morris: Bates No. 2023528821/8893. http://legacy.library.ucsf.edu/tid/ edt78e00. Accessed May 23, 2003.

87 Philip Morris. Results of inflight air quality study released. July, 1989 Philip Morris: Bates No. 2501042810/2811. http://legacy.library.ucsf.edu/tid/ dkh22e00. Accessed May 23, 2003.

88 Bonnier I. ETS media relations plan Nordic Area, Ingemo Bonnier 921019, 8th Revised Version. October 19, 1992 Philip Morris: Bates No. 2028398185/8194.. http://legacy.library.ucsf.edu/tid/goi87e00 Accessed May 23, 2003.

89 Leander S. SAS flies smoke-free in Europe Approximately 90 percent of SAS's routes in Europe will be smoke-free as of 000328 . AFTENPOSTEN; March 23, 1993 Philip Morris: Bates No. 2500053405. http:// legacy.library.ucsf.edu/tid/lif42e00. Accessed May 23, 2003.

90 Philip Morris. Agenda. May, 1993 Philip Morris: Bates No. 2501042010/ 2028. http://legacy.library.ucsf.edu/tid/wru22e00. Accessed May 23, 2003.

91 Ban on smoking goes up in smoke. Anti-smokers protest against SAS again allowing smoking on flights in Europe that last up to two and a half hours. SAS says that smokers have threatened to use other airline companies. Asker Baerums Budstikke; May 26, 1993 Philip Morris: Bates No. 2500053442/ 3443. http://legacy.library.ucsf.edu/tid/mgi19e00. Accessed May 23, 2003.

92 Winokur MN. Airline smoking bans. July 26, 1993 Philip Morris: Bates No. 2500016673/6674. http://legacy.library.ucsf.edu/tid/gzb19e00 Accessed May 25, 2003

93 Action on Smoking and Health. SAS goes smokefree. September 8, 1997 http://www.no-smoking.org/sept97/9-8-97-1.html. Accessed May 25, 2003.

94 Hong $M$, Bero L. How the tobacco industry responded to an influential study of the health effects of secondhand smoke. BMJ 2002;325:1413-6.

95 Ong E, Glantz S. Constructing "sound science:" tobacco, lawyers, and public relations firms. Am J Public Health 2001;91:1749-57.

96 Besques J, Skonnord A. Scanair. March 28, 1988 Philip Morris: Accessed May 23, 2003. Bates No. 2501042723A/2724. http:// legacy.library.ucsf.edu/tid/rih22e00.

97 Eatough DJ, Caka FM, Crawford J, et al. Environmental tobacco smoke in commercial aircraft. Atmospheric Environment 1992;26:2211-8.

98 Drake JW, Johnson DE. Measurements of certain environmental tobacco smoke components on long-range flights. Aviation Space \& Environmental Medicine 1990;61:531-42.

99 Oldaker GB, Conrad FC. Estimation of effects of environmental tobacco smoke on air quality within passenger cabins of commercial aircraft. Environ Sci Technol 1987;21:994-9.

100 Tobacco Institute. K: Airlines (1312) the Tobacco Institute Public Affairs Division Proposed Budget and Operatingplan 1989 (890000). September 14, 1988 RJ Reynolds: Bates No. 506785593/5607. http://legacy.library.ucsf.edu/tid/ueh44d00. Accessed September 25 2003. 
101 Tobacco Institute. Smoking aboard airliners: a strategic plan. No Date, Tobacco Institute: Bates No. TIOKO025439/5456. Oklahoma AG. http://legacy. library.ucsf.edu/tid/olt91f00. Accessed September 25, 2003.

102 Tobacco Institute. Further legislative action on airline smoking unwarranted. Congress should await DOT study. No public demand. June 22, 1989 Tobacco Institute: Bates No. TIMN0024768/4769. Minnesota AG. http:// legacy.library.ucsf.edu/tid/wvk03f00. Accessed September 25, 2003.

103 Winokur M. IACO [sic] Status Report. 1992 Philip Morris: Bates No. 2024201547/1548. http://legacy.library.ucsf.edu/tid/mja35e00. Accessed September 25, 2003.

104 Winokur M. Airline Smoking. March 9, 1992 Philip Morris: Bates No. 2046247158/7159. http://legacy.library.ucsf.edu/tid/ejy92e00. Accessed September 25, 2003.

105 Boyse S. ICAO Airline Ban. September 25, 1992: Bates No. $300544346 /$ 300544347. Available from Guildford Depository. Accessed November 21, 2001.

106 Anon. British Airways smoking bans proposed strategy. 1993/E: Bates No. 502554858/502554859. Available from Guildford Depository. Accessed November 21, 2001.

107 Johnson FR, Nabisco R. As Chairman and Chief Executive Officer of RJR Nabisco, Inc. I want to express my extreme disappointment with Northwest Airlines' decision to ban smoking on all its flights within North America. March 29, 1988 RJ Reynolds: Bates No. 506646914/6914. http:// legacy.library.ucsf.edu/tid/whv44d00. Accessed September 25, 2003.
108 Winokur M. British Air ban. August 16, 1993 Philip Morris: Bates No. 2024203670. http://legacy.library.ucsf.edu/tid/xha35e00. Accessed September 25, 2003.

109 Winokur M. BA smoking ban. August 5, 1993 Philip Morris: Bates No. 2024191426. http://legacy.library.ucsf.edu/tid/zkl34e00. Accessed September 25, 2003.

110 Winokur M. BA tactics. August, 1993 Philip Morris: Bates No2024203673. http://legacy.library.ucsf.edu/tid/zha35e00. Accessed September 25, 2003.

111 Sprinkle-RS-III. No Title. November 3, 1983 American Tobacco: Bates No. MNAT00517180. http://legacy.library.ucsf.edu/tid/dws44f00. Accessed September 25, 2003.

112 Anderson J. Lorillard inspires pro smoking mail. January 19, 1973 Lorillard: Bates No. 03742088/2089. http://legacy.library.ucsf.edu/tid/chx61 e00. Accessed September 25, 2003.

113 Hager JHA. Tobacco Institute request for letters in opposition to CAB, further restrictions on smoking on commercial aircraft. November 3, 1983 American Tobacco: Bates No. MNAT00517181. http:// legacy.library.ucsf.edu/tid/ews44f00. Accessed September 25, 2003.

114 Bateman R. Request for Philip Morris employees to oppose further Civil Aeronautics Board restrictions on smoking on airplanes. October 27, 1983 Philip Morris: Bates No. 1003192455. http://legacy.library.ucsf.edu/tid/ tru94e00. Accessed September 25, 2003. 